\title{
The Contemporary Significance of Confucius Doctrine of Filial Piety
}

\author{
Wenyan Feng \\ College of Marxism, Dalian Ocean University, Dalian, China
}

Email address:

Fwy01@126.com

\section{To cite this article:}

Wenyan Feng. The Contemporary Significance of Confucius Doctrine of Filial Piety. Humanities and Social Sciences. Vol. 5, No. 2, 2017, pp. 75-78. doi: 10.11648/j.hss.20170502.14

Received: February 27, 2017; Accepted: March 31, 2017; Published: April 6, 2017

\begin{abstract}
Ceremony Disintegration in the Spring and Autumn Period and the Warring States Period. In order to establish a better world, Confucius appealed to the thought of "filial piety" vigorously, for example "piety was a person's basic conduct", and made it systematized and deeply. Today, we should hold the Confucius Doctrine of Filial Piety and make it great. This has modern positive significance for maintaining the stableness of family and society, for Constructing the ethical ideology according with modern spirits.
\end{abstract}

Key words: Confucius, Filial Piety, Contemporary Significance

\section{Introduction}

Filial piety is a conventional norm of ethics and morals most vital to Chinese, and is considered one of the most important branches in Chinese traditional ideology and culture. Great educator - Confucius was the ancestor for filial piety of Confucianism. The study objective of this paper is considering that the doctrine of filial piety is extensive knowledge and profound scholarship: Confucius' moral idea system take filial piety as base, courtesy as norm, loyal and considerate as consistent and golden mean as criterion; including, revealing the connotation, historical limitation and temporary significance of Confucius doctrine of filial Piety thought. The paper makes great sense not only in understanding the national characteristics in Chinese history and culture, but in motivating modern Chinese people to inherit and advocate Chinese traditional culture, to practice filial piety, and to promote the social morality as well.

In this paper, the Marxist materialist dialectics and methodology of Marxist materialism as a fundamental searching method, and using comparison, literature, case analysis and so on. The purpose of writing this paper is not only in understanding the national characteristics in Chinese history and culture, but in motivating modern Chinese people to inherit and advocate Chinese traditional culture, responding to the aging society and building the harmonious and socialist society. And that's where the ultimate purpose of this paper lies.

\section{The Connotation of Confucius Doctrine of Filial Piety Thought}

\subsection{The Background of Confucius Doctrine of Filial Piety}

In the Chou Dynasty emerged greatly filial piety, but as ethical norm filial piety also was a important composition of courtesy of Chou Dynasty. Considering filial piety was related directly to economic base of which the agricultural production seen as main body and patriarchal clan system; only it emphasizes filial piety, it can reinforces rule and maintains social order. When comes ear Spring and Autumn and Warring States in which Confucius Lives, economic base and patriarchal clan system has experienced great change: the well field system trends to disintegrate the system enfeoffment has been disrupted, the patriarchal clan system has encountered serious impact, in the states, emerged many phenomena including "excluding relations, but admission of concubine" and excluding older son, but admission of young son, as wall as there were events of that officials kill ruler and sons kill father, courtesy of Chou Dynasty has been damaged severely. Thus, vacillation of filial piety was not doubt.

In the Era of Warring States, filial piety again became more declined. Faced of the social crisis, Confucius proposes, that state must correct the confusable social order and invertible human-ethical relationship, located the filial piety----moral 
training in the first position of learning and hard thinks to create a world that it fills with the kindheartedness.

\subsection{Fundamental Content of Confucius Doctrine of Filial Piety}

Confucius ethical system's core is kindheartedness. It not only is source of filial piety----human nature, but also is final goal that filial piety should hard implement. Original meaning of filial piety is that children provide charitable deeds for their father and mother, but Confucius related him to highest principle kindheartedness and makes it to become "foundation to make itself as good human[1]"He argued that, any man pursue filial piety, this means that he just begins to train himself, if every man all over the world can implements filial piety, thus, people defy one's superiors and starts a rebellion have been direduced, social morally prevailing custom just became very good, achieved world become kindheartedness. The status of filial piety is very high.

In order to promote the moral values of filial piety, Confucius conducted a profound theoretical system of filial piety. Confucius elaborated on filial piety focused on "Analects of Confucius", in which there is a direct reference to filial piety as many as nineteen words, related to the concept of filial piety has nearly twenty place. Its theoretical system including several parts below.

\subsubsection{Supports and Wait Upon}

For this point, Confucius talks less about it, because support and wait upon of material life has been seen obligation by people. If one who does not implement support and wait upon has been dislocated out of people by seen Confucius and been not spoke. Dan, Confucius argued, that it was not enough to support for children, they also implemented filial respect and filial obedience.

\subsubsection{Filial Respect}

Confucius emphasized, that you must hold sincere for your mother and father; if there was the support and wait upon in the material, but there was not filial respect in the spirit, there was filial duty as filial duty of dog and horse, or you only know to support parent, but do not know to respect parent.

About how you implement support and respect, Confucius provided several suggestions: first, filial appearance, or when children support parent, their complexion should be joyful. "Zi Xia asks filial, Confucius answers Complexion deem ugly. There're difficulties in it. The pupils all help him to overcome difficulties. There are alcoholic drink and foodstuff, Confucius offers food, are you think it is filial? [2]" One often keeps happy looks, it is difficult indeed. However, Confucius thinks: "If filial children hold deep love for their parents, they will hold amiable manner; if they hold amiable manner, they should hold happy appearance; if they hold happy appearance, they hold tortuous appearance. [3]" Second, filial thinking. When you face your parents, you should hold filial appearance; when you are not beside your parents, you should always think and concern your parents.

Meng Wu asked about filial piety, Confucius said: "Parents only fear for their illness. [4]" This means that parents only need to worry about their own bodies, do not worry about other matters. Confucius said: "While parents are alive, the son may not go abroad to a distance. If he does go abroad, he must have a fixed place to which he goes. [5]" even if excursion, you should also keep the information with parents' communication, keep parents in mind.

\subsubsection{Filial Obedience}

It means that you should support and wait upon parents with all your heart, obedience their wish and do not violate them. It is named by Confucius as do not violate. Meng Yizi asked about filial, Confucius answers, do not violate. Fan Chi safeguards, Confucius talks him, Meng Sun asks me about filial Piety, I talk him do not violate. Fan Chi asks: "what is it?'Confucius answers: 'live, deal with them with courtesy; die, bury with courtesy, sacrifice with courtesy. [6]" Or you should obedience for parents; Again, Confucius talks: "If you deal with parents with several proposals, if you find that they do not obedience with firm, but respect them and do not violate as well as keep attitude that you work hard, but do not feel resentful.[7]" Confucius argued that if their parents break the rules, their children can persuade and advise tactfully them; but, when their proposals been not accepted, still maintain the respectful attitude, do not violate their parents' wish, even though they feel depressed, but do not feel the resentment.

\subsubsection{Filial Funeral Arrangement, Filial Memory and Observing Period of Mourning}

Confucius specially attaches importance to filial piety that descendants treat parents and ancestors who has dead. He talks, One's of that we must consider are the people, food, funeral and memorial ceremony. He criticized his pupil Zai Wo without filial piety for him; it means there is not kindheartedness for him, because he only keeps 1year of observing period of mourning, Zai Wo asks: 3 year of period of mourning, or its time has been too long. A man of noble character does not hold courtesy, the courtesy will be destroyed during period of 3 years; one does not hold activities of music, the music will collapses during period of 3 years. Past all cereal has been eaten, new cereal will rise; boring flint to get fire, the time comes, its event will emerge. Confucius answers: "Eat rice, wear silk, live an extravagant life, are you comfortable? [8]" Zai Wo answered: "I feel at ease. [9]" "You can do it if you feel at ease. Gentleman is in mourning, he doesn't eat sweet, he is not happy when he listens to the music; he is not comfortable when he stayed, thus does not work for it Now, you feel at ease, you can do. [10]" Zai Wo went out. Confucius said: "It would be inhumane. Children grow up to 3 years old and then leave their parents embrace. Yet, there are holding mourning during 3 years, it was common sample about mourning in the world. Do you love your parents during period of 3 years? [11]" It is clear that how does he paid the importance to courtesy that one observes a period of mourning for 3 years.

\subsubsection{Loyalty and Filial Piety}

Confucius also increased new contents to the loyalty and 
filial piety. For example, in the ancient patriarchal society, loyalty and filial piety are two sides of a thing, the filial piety in the clan commune means that loyal to the monarch. Filial piety that Confucius often talks about also was linked to that it was loyal to monarch. However, Loyalty that Confucius advocates is not blind loyalty, as the time and after it, slave owners and feudal Lords emphasized, regarded as the monarch of slaves, obedient to absolute obedience. Instead, he advocated that is the do not bully, and invading, is certainly not misled his majesty, but to dare to commit the monarch, correct the king promptly. He argued, monarch and Minister are clear. The monarch should envoy to the ceremony; the minister must to obey the allegiance. For the filial piety is not blindly filial, not to die if parents request them to die, but mainly honor them. This is a breakthrough to the blind loyalty.

\section{Historical Limitation and Temporary Significance of Confucius Doctrine of Filial Piety}

Undeniable, Confucius doctrine of filial piety has progressive significance and important status in the ethics history. He abandoned the traditional moral norm of religion and aristocracy, replaced them with the social and general new spirit of morality; he does not put morality as a slave-owning aristocracy of patents, but spread to folk to put it is seen as in need of social life.

\subsection{Era's Limitation of Confucius Doctrine of Filial Piety}

First, it is based on the principle of inequality between father and son. Father has absolute authority to their children. Father observes their will, but father does not observations; if father die, they also cannot change father's morality during period of 3 years, they implemented filial duty. This is the conservatism of his doctrine of filial piety; Secondly, Confucius combines filial duty and filial piety has political purpose. Such as pupil entries, he implements piety; he must be prudent and sincere; he must broadly love multitude and closes relationship to kindheartedness; he has double powers to act and uses them to study culture. If they more early train their children as obedient pupils in the family, then, they seem like young, but still are filled with natural instinct. After adults, they can transfer filial piety to loyalty, with attitude that they treat their father and elder brother towards the monarch, from a filial son became a loyal official.

This is essence of Confucius doctrine of filial piety, which depends on filial piety as base of kindheartedness, starts from the political needs, and then services to maintain the patriarchal hierarchy, which are the limitations of Confucius doctrine of filial piety.

\subsection{The Contemporary Significance of Confucius Doctrine of Filial Piety}

In the contemporary era, Confucius filial piety thought has a great positive significance for us to promote respect for the elderly, and support the elderly consciously, maintain social stability and social harmony if take out the negative thoughts. China is gradually entering the aging society; the pension problem has become a big social problem. Although the national policy is a powerful means of management, but the morality also plays an important role in it. In the current society, carrying forward Confucius filial piety is an auxiliary method to solve the problem of old age society.

\section{Conclusion}

By recuperating the true nature of Confucian thought of filial piety, this paper makes great sense not only in understanding the national characteristics in Chinese history and culture, but in motivating modern Chinese people to inherit and advocate Chinese traditional culture, to practice filial piety, and to promote the social morality as well. And that's where the ultimate purpose of this paper lies.

Preaching to the young, cultivate their filial piety, making them love family, love community, love nature, love our country. It is an indispensable political and ideological work for building a socialist harmonious society.

\section{Acknowledgement}

Humanities and Social Sciences Research Fund Project of Ministry of Education of the People's Republic of China:

Discourse innovation of ideological and political education in Colleges and universities in the perspective of the convergence media. (16YJC710008);

Philosophy and Social Science Fund Project of Liaoning Province: Discourse innovation of ideological and political education in Colleges and universities in the network era (L14CSZ052).

General project of Dalian Social Science Association: Research on the ideological and political education in colleges and universities in the perspective of big data. (2016dlskyb156)

Cultivating personnel of ideological and political education outstanding young talent support program of Liaoning province, 2016.

\section{References}

[1] QianXun. Confucianism Canon - the "Analects of Confucius" [M]. Kunming: Yunnan people's publishing house, 2001, pp. 23

[2] QianXun. Confucianism Canon - the "Analects of Confucius" [M]. Kunming: Yunnan people's publishing house, 2001, pp. 32

[3] QianXun. Confucianism Canon - the "Analects of Confucius" [M]. Kunming: Yunnan people's publishing house, 2001, pp. 37

[4] Kang Xuewei: the study of filial piety" [M]. Jilin People's publishing house, 2000, pp. 56

[5] Yang Bojun, Yang Fengbin: The Analects of Confucius [M]. Yuelu Publishing House, 2011, pp. 35 
[6] Yang Bojun, Yang Fengbin: The Analects of Confucius [M]. Yuelu Publishing House, 2011, pp. 36

[7] Yang Bojun, Yang Fengbin: The Analects of Confucius [M]. Yuelu Publishing House, 2011, pp. 43

[8] Xiao Qunzhong. Filial piety and China culture [M]. Beijing: People's publishing house, 2001, pp. 68

[9] Xiong, Yanhua. Seeing Confucius's Concept of Filial Piety and
Its Contemporary Implications in Confucian Analects [J]. Journal of Hubei Engineering University, 2015

[10] Qian, GengSen, and S. Z. Shen, Ecological Civilization and Confucius and Mencius' Theory of the Benevolent Loves Others [J]. Qilu Journal, 2016

[11] Li, H. E. and T. University. On Confucius's Interpersonal Strategy [J]. Journal of University of South China, 2016 